\title{
Japan's Arcade Games and Their Technology
}

\author{
Y. Sambe \\ CTO Executive Director of TAITO Corp.
}

\begin{abstract}
The Japanese computer entertainment market is $\$ 20$ billion in size. Of that, the arcade market makes up the biggest share of revenue ( $\$ 6$ billion), with the home market and mobile phone market following at $\$ 3.5$ billion and $\$ 2$ billion, respectively. Abroad, however, home console gaming dominates and revenues from arcades make up only a small portion of the total market. In this session, I will introduce the arcade machines and supporting technology, discuss reasons for the enduring widespread popularity of arcade gaming in Japan, and explore potential directions for the future of arcade technology .
\end{abstract}

The Author. 1979 Joined Taito Corporation. Worked in the field of arcade machine research and development. 1992 Invented network karaoke (via server \& client karaoke machines), transforming the service into a viable business. 1995 Established the home network karaoke business. 1995 Promoted to Executive Director. 1999 Founded TAITO's mobile content business. 2004 Assigned as Senior Executive Director. 2006 Created TAITO's Key Technology Research Center R\&D Division for new business 2007 Named TAITO's Chief Technology Officer (after resigning as Senior Executive Director).

Awards. 1993: Nihon Keizai Shimbun: Recognition for establishing the network karaoke business. 1995: Nihon Keizai Shimbun: Recognition for contributions to the home network karaoke business. Member of The Institution of Professional Engineers, Japan Technology Committee Member of CESA (Computer Entertainment Supplier's Association) 